\title{
Continuous Education through Building a Work-and-Learn Relationship: How Does the Industrial Attachment Program Work in Hong Kong
}

\author{
Peter ChunYu Yau, Dennis Wong, and Andrew Lam
}

\begin{abstract}
In this paper, we reviewed the current university funding situation in Hong Kong for the past five years. We also reviewed the trend of student enrollment numbers to tertiary education in contrast to the support of the continuous education fund (CEF) for citizens. How personal development was build and how the programs were organized will be discussed. An in-depth analysis of the Industrial Attachment (IA) program (sometimes may be called internship program) was studied via three case studies, to understand the program arrangement, effectiveness, and impaction towards the sense of continuous education from the students' perspective. The case studies we provided include former students sharing their training experience gained from working in a software development house, a financial institute, and a school respectively. Results showed that the industrial attachment program gives various positive implications to the participants in academic, career, and life-long perspectives, which life-long implication is the one affected students the most among the three.
\end{abstract}

Index Terms - Continuous education, industrial attachment program, work and learn, Hong Kong, education.

\section{INTRODUCTION}

In Hong Kong, there are 30 post-secondary schools offering tertiary education to Hong Kong students in which 22 of them are degree-awarding institutes [1] and 8 of them are university grants committee (UGC) funded [2]. The UGC-funded schools are sponsored by the Hong Kong government. According to the figures by the education bureau, there are 74,848 undergraduate students in the academic year 2012/13 and 84,524 undergraduate students in the year 2018/19 [3], which is equivalent to an increase of $12.92 \%$ in six years' time (Fig. 1).

The total number of undergraduate's enrollment is increasing, so does the students under a research postgraduate degree which amount to around $11.14 \%$ increase in the same time frame. Taught postgraduate number has decreased slightly from 3,475 in the year $2012 / 13$ to 2932 in 2018/19 $(-15.62 \%)$. The total number of postgraduate enrollments remains steady, with 10,593 in the year $2012 / 13$ to 10,843 in the year 2018/19 [3].

The Hong Kong government has established a Continuing Education Fund (CEF) in 2002 which aimed at subsidizing

Manuscript received March 30, 2020; revised June 22, 2020.

P. Yau is with the School of Continuing and Professional Education, City University of Hong Kong, Hong Kong (e-mail: peter.yau@cityu.edu.hk, pyau@ieee.org).

D. Wong is with SUNY Korea, Korea and Stony Brook University, USA (e-mail: dennis.wong@sunykorea.ac.kr, cwong@uoguelph.ca).

A. Lam is with Clixells Research, Hong Kong (e-mail: andrewlam@clixells.com). adults aged between 18 and 70 to pursue continuing education and training. According to the figures from the Working Family and Student Financial Assistance Agency (WFSFAA) [4], there are 304 unique training providers in Hong Kong offering 9,756 in twenty-three (23) sectors, such as engineering and technology, language, business and management, law, medicine, dentistry and health sciences, etc. Each eligible Hongkongers receives a 20,000 Hong Kong dollars subsidy after successful completion of a course.

Apart from the education subsidy program, there are lots of training programs that are available to the young generation. Program providers believed that these training programs can supplement important practical learning experience to apart from the traditional education. These programs also serve as a personal growth training as a whole-person exercise. Students can found these programs from the government office [5], [6], in commercial sector businesses [7], [8], in universities [9], [10] and in post-secondary schools [11], [12].

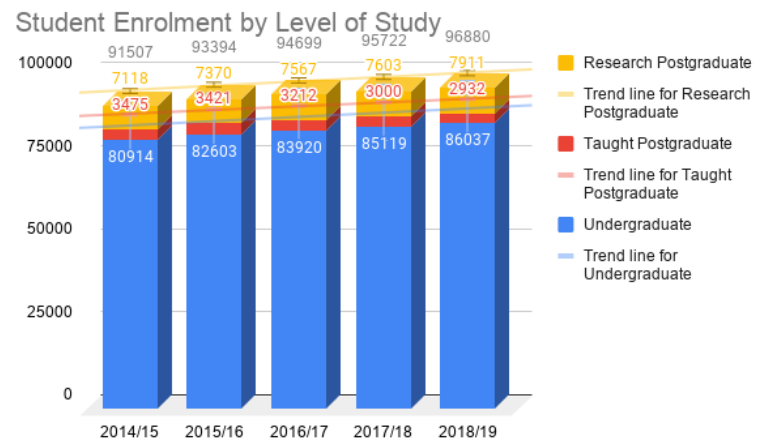

Fig. 1. Student enrolment number by the level of study.

In this paper, we conducted an in-depth analysis to understand how the industrial attachment program affects students' perception to their future career and their willingness towards pursuing continuous education and advance study in their career.

\section{LITERATURE}

In this section, we provide the basic structure of the Industrial Attachment (IA) program and the latest information about the program.

\section{A. Relationship Between Work and Learn}

Numerous studies have shown that students who work in academia or a career-related job show a higher level of commitment to their major study, present a better 
engagement to their workplace, and are more ambitious when compared to the students whom work in a non-career related job [13].

Having a work experience is an important factor leading to the success of some postgraduate degrees, such as a Master of Business Administration (MBA) degree. Some studies show that having a work experience is a more important criteria when compared to other admission criteria such as GMAT score in some programs [14].

\section{B. Role of Personal Development}

Self-awareness [15], self-knowledge [16], human-capital [17], and aspirations [18] are some of the vital elements in the personal development theory (Fig. 2) related to the industrial program, leading to the success of building a student's career. During the self-confidence formation process: identity and leadership skills can be grown through the role mode effect. A fresh trainee needs a good mentor to teach them how to lead a team in a workplace [19]-[21] and how the job can be done, etc. Without a good mentor, some intangible knowledge cannot be easily inherited to the next generation. This is also how the self-image formation can be achieved in certain professional industry, such as wearing a uniform required by some occupations [22].

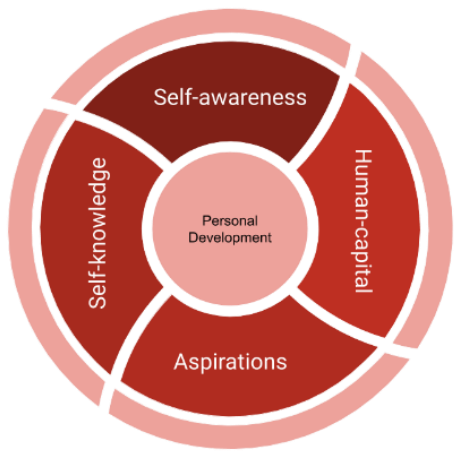

Fig. 2. Elements to buildup personal development.

\section{How the Industrial Attachment Program Works}

In the industry attachment program, students are usually assigned to a major degree-related training to work in a workplace. Some allowance would be given to the students, which is partially paid by the workplace employer and partially sponsored by the school. A mentor from the workplace would monitor the progress and performance of the students and co-supervise the students with a teaching staff. If the work requires traveling outside of the Hong Kong region, for example, traveling to a nearby city such as Macau or Shenzhen, the school and the industry partner would provide lodging, meal and transportation between the factory and the dormitory. The school would also assist to prepare the paperwork required for applying for a work visa if that is required.

\section{Points to Note about the Program}

Below are several important points to note for preparing the industrial attachment program for the sake of the students' safety concerns and also to comply with the local legal regulations.

1) Insurance: in most of the cases, students studying in Hong Kong are covered by the group personal accident insurance policy from the schools to protect their activities within the school premises and some agreed areas. Schools and students should pay attention if their industrial attachment program and also the places they are going to work are well-covered by their current polices, or a new policy shall be acquired.

2) Minimum Wage Ordinance: The Hong Kong government has passed the minimum wages ordinance (Cap. 608) on November 12 ${ }^{\text {th }}, 2010$ (L.N. 146 of 2010). Cap. 608 Section 7-4 of Part 1 states the following - "This Ordinance does not apply to a student intern.", that mean student internships are not bound by the minimum wage ordinance.

3) Mandatory Provident Fund (MPF): The MPF is the retirement fund contribution scheme proposed by the Hong Kong government in the year 2000. Both the employer and the employee are required to contribute $5 \%$ of their monthly salary to their MPF account until the employee reaches his/her retirement age. Although there is an employer-employee relationship between the students and the training providers in the industrial attachment program, neither of them is required to sign an employment contract in this period. As a result, the MPF contribution scheme does not apply to the industrial attachment program.

\section{Industrial ATtachment PROGRAMS IN HONG Kong}

\section{A. Institutes Participation}

This study found that all the University Grants Committee (UGC) funded universities in Hong Kong provide an industrial attachment program or something similar to their students. The program title can be different though, for example: the Metropolitan Attachment Program (MAP) by Hong Kong Baptist University (HKBU), the Internship program (IP) by the Lingnan University LU) and the Placement and Internship (PIP) program by the Chinese University of Hong Kong.

Apart from the UGC-funded universities, non-UGC funded and other award-bearing tertiary institutes also provide similar programs. For example, the Vocation Training Council (VTC), an industry-and-work oriented institute, and the Hong Kong Shue Yan University (HKSYU), a private university in Hong Kong also provide similar programs.

\section{B. Work Experience}

There are various categories of jobs provided by these training programs. The majority of these programs only allow university students to apply, while some of them also allow high school graduates to apply when they are about to admit into a university. One of the reasons why the majority of these industrial training programs are only available to university students is possibly due to the fact that the schools and also the employers believe these on-site trainings can greatly enhance the students' work capability. Further, the time arrangement of college students is more flexible when compared to students studying in other kind of institutes which usually have a fixed school timetable with long 
teaching hours.

Internship program also provides an overseas training opportunity to students. After the year 1997, Hong Kong was handover back to the Mainland China and the connection and communication between these two places are getting much closer [23]. Economy, city development, and research co-operation opportunities are plenty, given Hong Kong position as an international financial center and service sector provider, while the Canton province has a number of industrial and manufacturing cities and also a technology hub in Shenzhen. Training programs that take place in the Mainland China are becoming more popular. Some overseas placements also take place in places outside of the China region, such as the United States, the United Kingdom or Australia.

\section{Continuous Education Case Study}

During the work-supervision process, students can experience the professionalism required for their major study. A mentor is assigned to a student during the industrial attachment program who acts as a role model for the student to learn from. Due to the fast-changing technology and the fast pace of the society, the mentors and senior professionals who have worked in the industry for several years would possibly pursue their advance study after getting their first degree. The advance study can be related to a degree in another major, or a postgraduate study to advance their knowledge and technique. Under such influences, students can learn about their own career pathway.

In this study, we surveyed three working professionals who have experienced the training program (or any similar program with a different name) when they were having their tertiary education. Three questions were asked to understand the usefulness and the impacts of the industrial attachment related programs, they are:

1) Tell us about your background and your student life, with some information about how the industrial attachment program (or any similar kind) directly or indirectly affects you?

2) What do you think about this program? Please elaborate and justify.

3) Can the industrial attachment program improve? Why and how?

All the interviewees were surveyed anonymously in a one-to-one dialogue session, interviewees were aware that their responses would be used in this study to understand the changes of the program over the years. In the following part, the replies and the comments from the interviewees are consolidated.

\section{A. Student Trainee at Software Development House}

VU, male, born in 1980s, was a computer engineering student who studied at a local UGC-funded university. Prior to his tertiary education, he worked as a summer helper since his sixteen years old. He started his part-time work at a small-sized trading company as a computer technician. The reasons why VU worked for a part-time job was because of his wish to earn some pocket money without spending all his parents' money and to gain more exposure earlier in his career when compared to his peers. VU claimed that there is no such thing called industrial attachment program until he was a final year student for his undergraduate degree.

VU kept working for his part-time job until he completed his doctoral degree. All these years he had worked part-time in any company that has a vacancy. He gained a lot of experience and money, so he travelled to lots of places when he was free.

"Although I am just in my late 30s, if I can do it again, I don't want to work that early. Well, but I know, it's kind of my personality. I mean, I am a person that do not want to stop and is always looking for a new challenge. I know that having a doctoral degree can help me a lot in my career, but honestly, I just think of challenging myself when I did my doctoral degree."

Instead of participating in an internship program (the program title used when VU was a student), VU visited the firm where his classmate joined through the program. He checked that if the firm has any vacancy which has a better salary but with a different title: "Well, all jobs are similar, we just do programming. I can't see the difference for the job nature of these positions, but why can't I have a better salary and most importantly, a better title (when I was junior)."

"To me, I am a self-motivated person. Personally, I do not think that I am suitable for the industrial attachment program. I believe the industrial attachment program is more suitable for people who do not look into the opportunities available in the market actively, and for those who don't want to take risk. Don't get me wrong, I am not saying it is meaningless, but just not my cup of tea".

\section{B. Student Trainee at Financial Institute}

LC, female, born in $1985 \mathrm{~s}$, was a student majoring in finance in a local UGC-funded university. LC did not have any casual job apart from being a private tutor after entering the university. Her students were introduced by her mother. She also did not have any commercial job experience until she joined the internship program.

LC participated in the student association which belongs to her department. She would like to know more about how finance works in a real workplace through joining the club. She also wanted to participate in various activities to gain more exposures (human capital). After the completion of her first-year study, she joined the internship program offered by the university. Through this program, she successfully entered an international financial firm as a student trainee. Her duty was mainly about data collection and organizing activities. At the time of her graduation, she received a full-time job offer from this financial firm and had continued to work as a finance professional.

Apart from the local training program, her university further extended her exposure with some overseas experience. LC went to Sydney for a two-months industrial attachment program which allowed her to work in an accounting firm. LC also took this opportunity to explore this overseas country, which is the first time she traveled to somewhere outside of Asia. Three years after her graduation, she pursued her postgraduate study in statistics in another local university. She worked in a new company after completing her master's degree and got promoted from her position.

"I would like to be financial independent; this is something I dreamt of when I was young. I would like to see more about 
the world", LC said. She mentioned that it was one of the reasons why she chose the internship offer when she was a second-year student: "it's cool and looks nice, I worked in Central, and worked at The Center, you know the office is on the 63rd floor". Central is the business center of Hong Kong, where most of the expensive office are located in Central.

'I planned to have my master's degree in statistics after I tidy up my life. After having the experience to work in the financial industry (through the internship program), I met lots of interesting people who aim high while enjoy their lives. I know I can try something new just like them".

"Many people would choose MBA as their next top-up degree, I found that this qualification is not as valuable as it thought. I have a co-worker who worked as a senior researcher and has received a $\mathrm{PhD}$ degree. I would like to have some scientific training rather than purely learning about the business knowledge".

"The industrial attachment program right now provides a very good networking opportunity to the students. It is good for you to meet more people so that you know what kind of people you would like to be". LC mentioned that she met her boyfriend in the workplace.

\section{Student Trainee at Fish Trading Company}

CC, male, born in 1990s, was a higher diploma student majoring in information technology who studied at a government-funded vocational education institute. CC claimed that students in vocational institutes are usually those who are weak in languages. He wishes to advance to a degree program after completion of his diploma. "Everyone knows that you can't get a good job without getting a degree" CC said.

He worked for several part-time jobs when he finished secondary school, such as working as a server in a restaurant, and a tele-operator at a betting control center of the Hong Kong Jockey Club. The reasons why he worked for these jobs were mainly due to his education qualification and his weak language skill. For these positions, college students accepted the same hourly rate as to what he had received.

"I know that the industrial attachment program can equip me better for future challenges. At least my resume can have one more job experience to write on it". CC successfully entered a university after completing his higher diploma. Although the program was not government-funded, he can still receive his bachelor's degree after completion of the program.

"I changed a couple of my jobs after graduation. Now I am considering doing a master's degree. I don't know if I am capable of doing that. But now I started to understand the use of the theory I learned from the classes when I do my bachelor's degree. The mentor I worked with at the bank during the internship period, I started to understand his teaching. I would be able to do much better if I can do it again".

\section{ANALYSIS AND INTERPRETATION OF RESULTS}

By interviewing three working professionals who have some experience with the internship program during their college time, we try to analysis how the program impacts the continuous education of students in various aspects:
1) From the academia perspective: all three interviewees had plans to pursue their postgraduate study after completing their undergraduate with several years of work experience. Although not all of them agreed that the industrial attachment program can be helpful for their career growth, all of them agreed it is a positive way to influence peers to achieve a better career planning. Interviewee LC claimed the program is highly useful, while the other two claimed that self-motivation is the most important factor for having a successful future.

2) From the career perspective: this part shares the same result as to the last analysis. Not all the interviewees agreed that they can be rewarded with what exactly offered by the program. They do agree that similar kinds of training can expand their horizon in terms of being a working professional. Interviewee LC claimed that she gained some fruitful relationships through the program.

3) From the life-long learning perspective: all the interviewees agreed that the industrial attachment program allows them to understand more about how the real-world works. By observing their mentors and also the seniors in their workplace; they can picture what they can achieve and how that can be achieved. Interviewee $\mathrm{CC}$ strongly supported that such program can help students whom are lack of vision planning and motivation for a better career opportunity via continuous education.

\section{CONCLUSION}

As we can see from the case studies, everyone has their own perception towards the industrial attachment program. We can see that the interviewees participated in this program perceive the program in many different ways, but eventually they can recall the memory they had experienced, and what they had treasured during the training period. No matter how self-motivated and underprivileged of the people they had met through this program, students can experience the difference and can likely convert these differences into a positive energy which drives them towards a better future. Some students used this program as a tool to enrich their social network, while some of them use it as a tool to expand their horizons. We concluded that the industrial attachment program or similar programs can facilitate the long-term continues education atmosphere.

\section{CONFLICT OF INTEREST}

Peter Yau is a former employee of AnchorStream Limited, which AnchorStream Limited continuously supported the industrial attachment program in Hong Kong for more than ten years. Peter did not hold any active position in AnchorStream Limited during the time of this research. The interviewees neither directly and indirectly related to the AnchorStream Limited nor receive any possible benefit from the study.

\section{AUTHOR CONTRIBUTIONS}

Peter Yau is responsible for the interview, data collection, 
analysis and paper writing. Dennis Wong is responsible for the idea generation, theory setup and project management. Andrew Lam is a junior researcher in the Clixells Research, responsible for the administration duties, logistics and presenter in the conference.

\section{ACKNOWLEDGMENT}

A heartfelt thanks given to the interviewees Dr VU, Ms LC, and $\mathrm{Mr} \mathrm{CC}$; without the support and meaningful interview, our research cannot be done.

The research work of Peter Yau is supported by the AnchorStream Limited, an information technology (IT) solution provider in Hong Kong.

The research work of Dennis Wong is supported by the Technology Innovation Program (or Industrial Strategic Technology Development Program (10053204, Development of business intelligence platform service which enables a non- expert to realize "Data Processing and User Interface" within 3 seconds in Petabyte level based on 0.5 billion data) funded by the Ministry of Trade, industry \& Energy(MI, Korea)", and the MSIT (Ministry of Science and ICT), Korea, under the ICT Consilience Creative program (IITP-2020-2011-1- 00783) supervised by the IITP (Institute for Information \& communications Technology Planning \& Evaluation.

The research work of Andrew Lam is supported by the Clixells Research, a virtual experience and branding solution provider in Hong Kong.

\section{REFERENCES}

[1] Educational and training institutions by level of education of courses offered. [Online]. Available: https://www.edb.gov.hk/en/about-edb/publications-stat/figures/edu-tra ining-institutions.html

[2] University Grants Committee Funding. [Online]. Available: https://www.ugc.edu.hk/eng/ugc/activity/funding.html

[3] UGC Commonly Used Statistical Tables. [Online]. Available: https://cdcf.ugc.edu.hk/cdcf/statSiteIndex.action

[4] Information for Course Provider. [Online]. Available: https://www.wfsfaa.gov.hk/cef/en/index.htm

[5] Administrative Service Internship Programme 2020. [Online]. Available: https://www.csb.gov.hk/english/grade/ao/279.html

[6] Post-Secondary Student Summer Internship Programme. [Online]. Available: https://www.csb.gov.hk/english/admin/appoint/782.html

[7] Students \& Graduates Recruitment: DHL. [Online]. Available: https://www.dhl.com/hk-en/home/careers/students-and-graduates.htm

[8] Student opportunities: HSBC Holdings plc. [Online]. Available: https://www.hsbc.com/careers/students-and-graduates/student-opport unities

[9] CUHK Global Internship Programme (GIP). [Online]. Available: https://cpdc.osa.cuhk.edu.hk/student/gip

[10] Career Center: The HKUST. [Online]. Available: https://career.ust.hk/web/page.php?section=find_a_job

[11] High School Internships. (May 18, 2018). [Online]. Available: https://www.nextstepconnections.com/high-school-internships/

[12] HKU Summer Institute for Secondary School Students. [Online]. Available: https://aal.hku.hk/admissions/local/hku-summer-institute-secondary-s chool-students

[13] J. P. Aper, An Investigation of the Relationship between Student Work Experience and Student Outcomes, 1994
[14] A. J. Adams and T. Hancock, "Work experience as a predictor of MBA performance," College Student Journal, vol. 34, no. 2, pp. 211-217, 2000.

[15] D. T. Hall, Self-Awareness, Identity, and Leader Development. In Leader Development for Transforming Organizations, Psychology Press, 2004, pp. 173-196.

[16] T. D. Wilson and E. W. Dunn, "Self-knowledge: Its limits, value, and potential for improvement," Annu. Rev. Psychol., vol. 55, pp. 493-518, 2004.

[17] A. Nelen and A. Grip, "Why do part-time workers invest less in human capital than full-timers?" Labour, vol. 23, pp. 61-83, 2009.

[18] L. S. Gottfredson, "Circumscription and compromise: A developmental theory of occupational aspirations," Journal of Counseling Psychology, vol. 28, no. 6, p. 545, 1981.

[19] K. Milisen, T. Busser, A. Kayaert, I. Abraham, and B. D. Casterle, "The evolving professional nursing self-image of students in baccalaureate programs: A cross-sectional survey," International Journal of Nursing Studies, vol. 47, no. 6, pp. 688-698, 2010.

[20] K. Siebens, B. D. Casterlé, I. Abraham, K. Dierckx, T. Braes, E. Darras, and $\mathrm{K}$. Milisen, "The professional self-image of nurses in Belgian hospitals: A cross-sectional questionnaire survey," International Journal of Nursing Studies, vol. 43, no. 1, pp. 71-82, 2006.

[21] D. Chênevert, G. Jourdain, and C. Vandenberghe, "The role of high-involvement work practices and professional self-image in nursing recruits' turnover: A three-year prospective study," International Journal of Nursing Studies, vol. 53, pp. 73-84, 2016.

[22] T. Fahkry, Awaken Your Authentic Self, Tony Fahkry, 2017.

[23] N. Sin. (September 5, 2019). Explainer: How important is Hong Kong to the rest of China? [Online]. Available: https://www.reuters.com/article/us-hongkong-protests-markets-explai ner/explainer-how-important-is-hong-kong-to-the-rest-of-china-idUS KCN1VP35H

Copyright $\odot 2020$ by the authors. This is an open access article distributed under the Creative Commons Attribution License which permits unrestricted use, distribution, and reproduction in any medium, provided the original work is properly cited (CC BY 4.0).

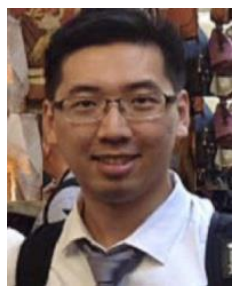

Peter Yau received his DBA from the University of Newcastle, Australia. He received his MMgmt from the Macquarie Graduate School of Management, Australia and a BSc (hon) major in computer science from the Chinese University of Hong Kong. He currently serves as a vice president at Cogaza Investment a start-up company focus in technology implementation in financial trade. He holds an active position as a researcher and lecturer at various institutes. His research interest includes cloud technology, embedded system and financial technology, MIEEE, MIET, MBCS, MACM.

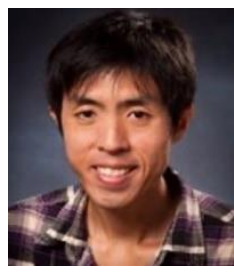

Dennis Wong received his $\mathrm{PhD}$ and $\mathrm{MSc}$ in computer science from the University of Guelph, Canada, and his BSc in computer science from the Chinese University of Hong Kong. He currently holds a joint position as an assistant professor at SUNY Korea and a research assistant professor at Stony Brook University. Before joining SUNY Korea, he was an assistant professor at the Northwest Missouri State University. Before that, he was a Roncesvalles postdoc researcher at the University of Guelph under the supervision of Joe Sawada and Aaron Williams.

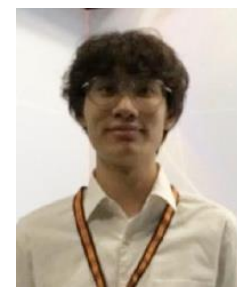

Andrew Lam received his BSc (hon) in computer science from Chu Hai College of Higher Education, Hong Kong. He currently holds a joint position as a research assistant in the industrial 3D augmented reality project and the unmanned smart shop laboratory development project, MIEEE. 